\title{
ENVIRONMENTAL STRATEGIC PLANNING RUMAH SAKIT PERSAHABATAN MENUJU A GREEN HOSPITAL
}

\author{
Sunarto ${ }^{1}$ \\ ${ }^{1}$ Universitas Kristen Indonesia (UKI) \\ email:yamasnarto@gmail.com
}

\begin{abstract}
:
The objective of this study is aim at finding out environmental strategic planning differences between what has been conducted by Persahabatan state hospital compared to theoretical prescription in building to be a green hospital. A descriptive-theoretical method has been applied for this purpose by implementing a content analysis which involved analyzing short/long term hospital strategic planning documents, 2015/2016. The results of this study revealed that environmental strategic management has been prepared in term of short (1 year) and long term (5 year plan), but it was not carried out in detail concern with budget and human resource allocation in accordance to their specialization in managing all green hospital concepts such as green building, the efficient use of electric energy, water, efficient use of papers, preventing air and water pollution, waste management, gardening, and building green corporate culture which emphasizing on environmental hospital performance. The later should be new concept in developing an environmental strategic planning as one of the contributions toward a green hospital which was neglected by some environmental strategic planning theories.
\end{abstract}

Keywords: environmental strategic planning, waste management, green building, environmental corporation performance, green hospital.

\begin{abstract}
Abstrak:
Tujuan dari penelitian ini adalah untuk mencari tahu strategic planning RS Persahabatan menuju green hospital. Metode deskriptif-teoritis telah diterapkan untuk penelitian ini dengan menerapkan analisis konten yang melibatkan analisis dokumen perencanaan strategis rumah sakit jangka pendek / panjang, 2015/2016. Hasil penelitian ini mengungkapkan bahwa manajemen strategis lingkungan telah dipersiapkan dalam jangka pendek ( 1 tahun) dan jangka panjang (rencana 5 tahun), tetapi tidak dilakukan secara rinci perhatian dengan anggaran dan alokasi sumber daya manusia sesuai dengan spesialisasi mereka dalam mengelola semua konsep green hospital seperti bangunan hijau, penggunaan energi listrik yang efisien, air, penggunaan kertas yang efisien, mencegah polusi udara dan air, pengelolaan limbah, berkebun, dan membangun budaya perusahaan hijau yang menekankan pada kinerja rumah sakit lingkungan. Kemudian harus konsep baru dalam mengembangkan perencanaan strategis lingkungan sebagai salah satu kontribusi terhadap green hospital yang diabaikan oleh beberapa teori perencanaan strategis lingkungan.
\end{abstract}

Kata kunci: perencanaan strategis lingkungan, pengelolaan limbah, green building, kinerja perusahaan lingkungan, green hospital. 


\section{PENDAHULUAN}

Rumah sakit dengan konsep "green" (ramah lingkungan) menempatkan kepentingan ekologis dalam kegiatannya masih jarang di temukan di Indonesia. Isu perubahan iklim dan pemanasan global yang telah disadari dampak negatifnya oleh banyak masyarakat dunia, seharusnya membuka kesadaran manajemen rumah sakit untuk andil dan berkontribusi mencegah dan mengendalikan dampak negatif tersebut. Kondisi diatas cukuplah dapat menjadi alasan yang kuat bahwa rumah sakit kedepan perlu melakukan langkah kongkrit melalui kebijakan"ramah lingkungan" yang menempatkan kepentingan ekologis dan keberlanjutan sumber daya alam dan lingkungan menjadi salah satu indikator dalam mengukur keberhasilan pelayanan dan mutu rumah sakit.

Rumah sakit berkontribusi pada kesehatan lingkungan dengan dampak yang signifikan baik di hulu maupun hilir pelayanan publik, melalui pemanfaatan sumber daya alam dan produk yang dikonsumsi serta melalui limbah yang dihasilkan. Saat ini hanya ada beberapa parameter yang terbatas yang digunakan untuk mengukur masalah dan dampak dari sektor kesehatan. Sebagai contoh, Menurut National Health Service (2009:2) di Inggris menghitung jejak carbon disektor kesehatan lebih dari 18 juta ton $\mathrm{CO}_{2}$ setiap tahun, mewakili $25 \%$ dari total emisi sektor publik. Stankovic (2009:1-8) melakukan evaluasi efisiensi energi yang diaplikasikan pada bangunan umum ( sekolah dan rumah sakit) di Serbia. Penghematan energi telah ada pada bangunan yang telah diperbarui dengan penghematan tahunan berkisar antara $15 \%$ sampai $63 \%$ dengan rata-rata $40 \%$ dari seluruh proyek.

Menurut International Trade Administration (2005:2) di Amerika Serikat sektor pelayanan kesehatan adalah pengguna terbesar bahan kimia, sebagian besar merupakan kimiawi penyebab kanker. Di China belanja konstruksi kesehatan melebihi US \$10 miliar per tahun dan berkembang sebesar $20 \%$ per tahun dan menggunakan sumber daya cukup banyak. Dampak rumah sakit terhadap kesehatan lingkungan bila dilihat dengan nilai 
ekonomi sektor kesehatan. WHO ( 2010), dalam Health in the Green Economy Co-Benefits to Health of Climate Change Mitigation. Health Facilities, pada tahun 2007 pengeluaran dari sektor kesehatan dunia mencapai US\$ 5.3 triliun, atau sekitar US\$ 639 per orang per tahun atau sekitar 8 sampai $10 \%$ dari Produk Domestik Bruto ( PDB ) dunia.

Studi Balifokus (2010) bersama Direktorat P2PL Kementerian Kesehatan dan WHO pada tahun 2010 dalam Assesment of Environmental Conditions and Inventory for Guidance and Technical Support to Develop Sound Management Practices for Hospital Wastes dilaporkan 6 rumah sakit di 3 kota yaitu Bandung, Medan dan Makasar, menunjukkan pemakaian air per unit satuan tempat tidur yang bervariasi antara 200 sampai 950 liter perhari per tempat tidur. Angka ini jauh lebih besar dari angka pemakaian air di hotel berbintang. Pengeluaran listrik per bulan juga bervariasi antara Rp 86.000 sampai Rp 380.000 per tempat tidur. Saat ini di Indonesia belum ada batasan atau kisaran penghematan energi atau hemat air untuk di rumah sakit.

Meskipun belum ada satu model rumah sakit yang berwawasan lingkungan "Green Hospital" yang baku, namun telah banyak rumah sakit dan sistem kesehatan di seluruh dunia yang berinisiatif mengurangi kerusakan lingkungan dengan cara berkontribusi terhadap kesehatan masyarakat dan pada saat yang sama juga menghemat penggunaan sumbar daya energi dan meminimalkan limbah rumah sakit. Untuk itu diperlukan suatu kebijakan dan strategic management melalui perencanaan strategik lingkungan agar dapat menjadi rumah sakit yang ramah lingkungan, yang efisien terhadap penggunaan energi listrik, air, penggunaan kertas dan pengelolaan limbah dan fokus pada masalah ramah lingkungan dan medis serta memperhatikan kenyamanan, keharmonisan dan kualitas hunian antara struktur bangunan dan lingkungan alami sekitarnya.

Isu lingkungan sampai saat ini menjadi sangat penting dibicarakan. Menurut Chiras (1991:3), lingkungan adalah segala sesuatu yang ada disekitar kita yaitu udara, air, daratan 
dan semua maklhuk hidup yang menjadi penghuninya. Menurut Miller (1985:454), lingkungan adalah keseluruhan kondisi eksternal yang memengaruhi kehidupan suatu organisme atau populasi.

Lingkungan wajib dikelola dengan baik melalui strategik manajemen lingkungan. Pada dasarnya manajemen lingkungan merupakan seni yang memerlukan pemahaman tentang interaksi antara manusia dengan lingkungan, keterampilan manajemen, diplomasi dan kemampuan persuasi . Dalam manajemen lingkungan terdapat hubungan yang erat antara sistem natural dengan sistem sosial.
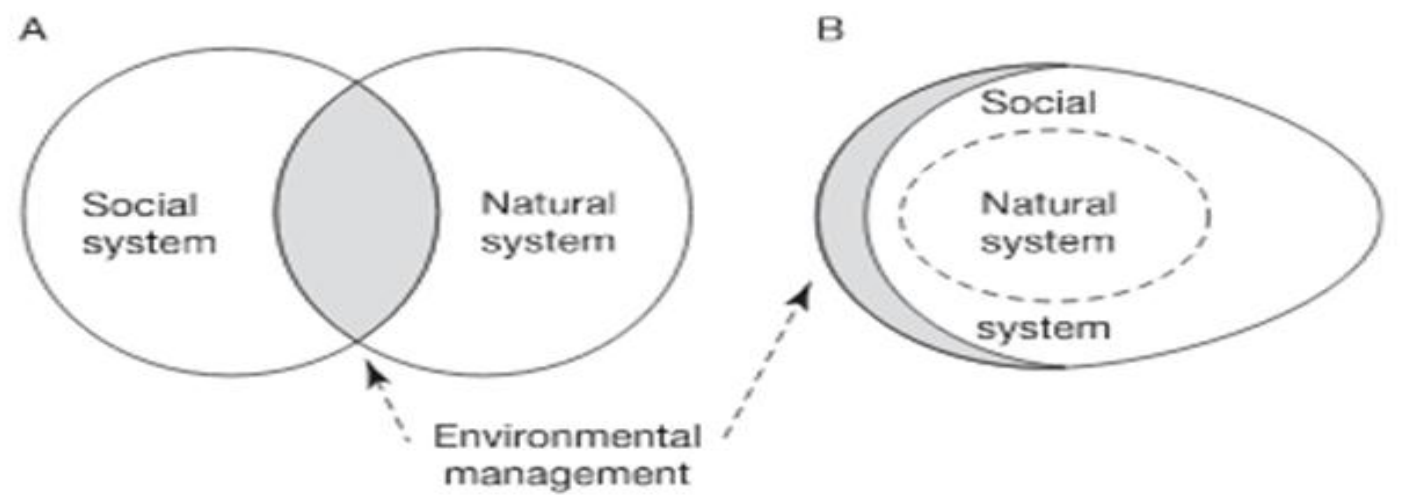

Gambar 1. Natural System and Social System Relationship (Barrow, 2006:41)

Berdasarkan gambar tersebut tampak bahwa sistem sosial mungkin dapat memengaruhi sistem alam. Pada umumnya hubungan timbal balik kedua sistem itu divisualisasikan seperti pada (A) gambar di atas dan bagian yang gelap adalah aktivitas utama dari manajemen lingkungan. Namun hanya beberapa saja lingkungan itu masih berupa alam murni, sebagian besar sudah dipengaruhi oleh kegiatan-kegiatan manusia. Oleh karena itu system sosial dan sistem alam tidak terlalu independen, sehingga pola hubungan seperti gambar (B) lebih mungkin dapat diterima . 
Lingkungan sangat berperan dalam pembangunan berkelanjutan. Konsep pembangunan berkelanjutan mencakup keterkaitan ketiga pilar pembangunan yaitu ekonomi, sosial dan lingkungan seperti yang diilustrasikan pada gambar 2 berikut

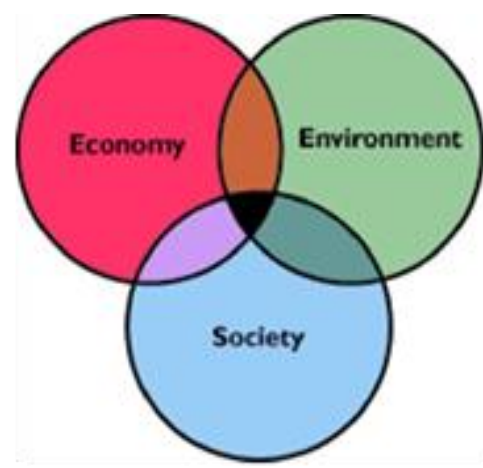

A

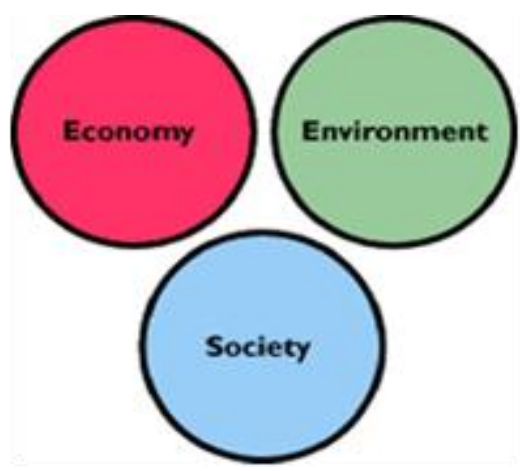

B

Gambar 2. Model Pembangunan Berkelanjutan Triangle (Ferdig:2007)

Berdasarkan uraian pada tersebut di atas, maka rumusan masalah yang diajukan dalam tulisan ini adalah "Bagaimanakah Strategic Management dengan focus perencanaan strategik lingkungan yang diterapkan di Rumah Sakit Persahabatan dalam membangun rumah sakit menuju Green Hospital"? Penelitian ini bertujuan mengetahui dan menganalisa perencanaan strategik lingkungan yang dilaksanakan di Rumah Sakit Persahabatan dalam upaya membangun rumah sakit menuju Green Hospital.

\section{METODOLOGI PENELITIAN}

Metode penelitian yang digunakan adalah metode deskriptif teoretik yaitu penelitian yang bertujuan menjelaskan bentuk dan pelaksanaan strategic management dengan focus perencanaan strategik lingkungan di Rumah Sakit Persahabatan dalam mewujudkan Green Hospital. Alur penelitian dengan menggunakan metode deskriptif teoretik dapat dilihat pada gambar di bawah. 


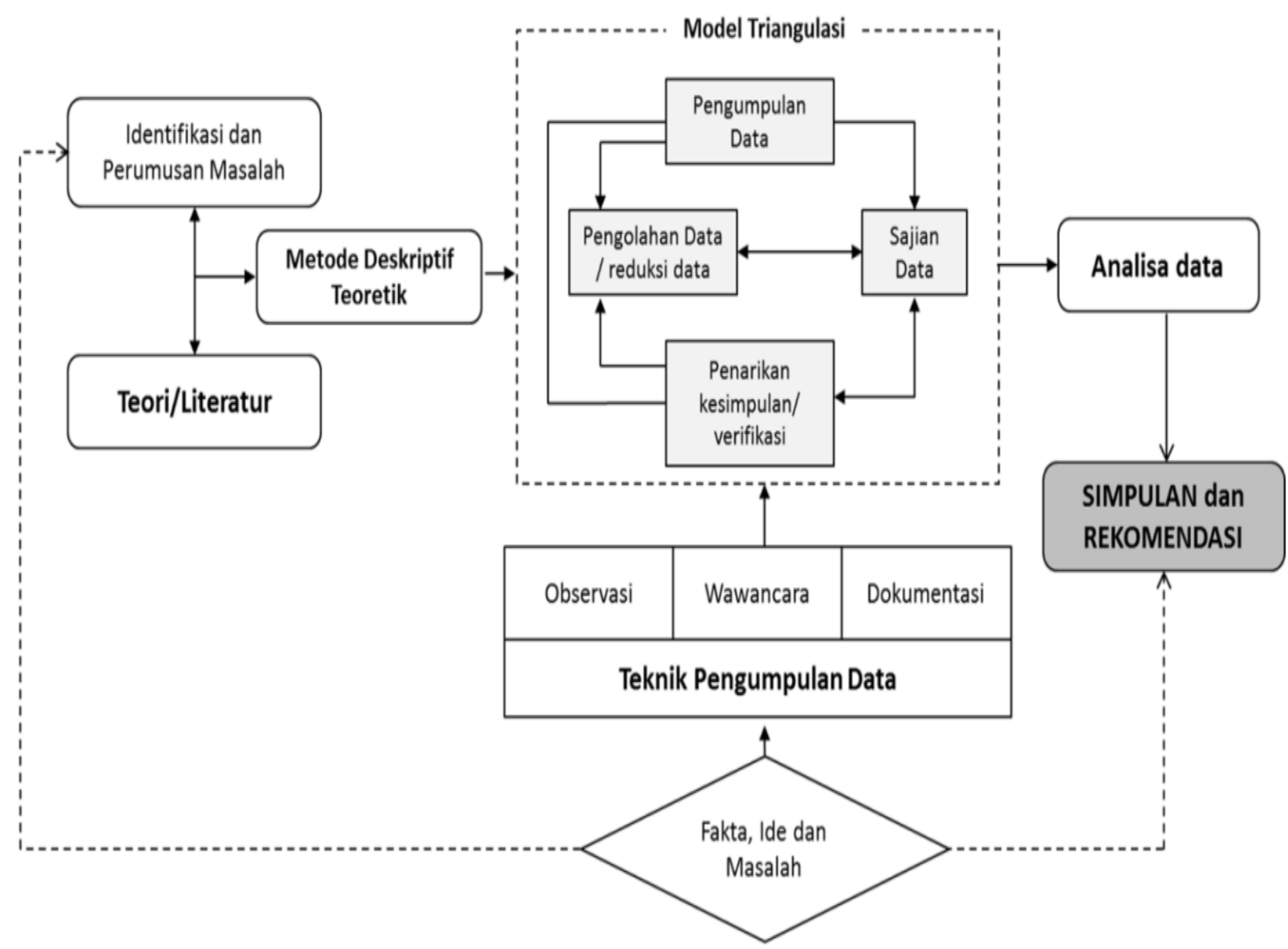

Gambar 3.Skema Alur Pengumpulan dan Analisa Data Penelitian

Pelaksanaan kegiatan penelitian disertasi ini terdiri dari beberapa tahapan. Pada setiap tahapan kegiatan diharapkan menghasilkan output yang dapat dicapai dan terukur. Teknik pengumpulan data yang diadopsi dalam penelitian ini meliputi melalui studi dokumentasi, observasi dan wawancara.Teknik ini memiliki kelebihan untuk memperoleh data dan informasi yang bersifat kualitatif. Instrumen penelitian yang digunakan adalah panduan wawancara (interview guidelines) yang digunakan pada saat pencarian data lapangan

\section{HASIL DAN PEMBAHASAN}

Temuan penelitian penerapan strategik manajemen di rumah sakit Persahabatan dalam mewujudkan green hospital melalui perencanaan strategik lingkungan. 


\section{Program Strategis Green Hospital RSUP Persahabatan.}

Kebijakan green hospital RSUP Persahabatan lahir atas respon manajemen RSUP Persahabatan saat itu untuk mendukung pencegahan dan pengendalian dampak lingkungan akibat isu perubahan iklim dan pemanasan global. Untuk mewujudkan tujuan program green hospital RSUP Persahabatan, maka diperlukan perencanaan strategis guna menjadi acuan dalam pencapaian visi dan misi green hospital. Penerapan rumah sakit ramah lingkungan (green hospital implementation) di Indonesia, saat ini telah berkembang menjadi pendekatan sisi baru dalam mengelola rumah sakit. Rumah sakit ramah lingkungan dalam perancangan pembangunan, pengoperasiannya dan pemeliharaannya dapat menerapkan prinsip keberlanjutan dan praktik-praktik ramah lingkungan.

Kebijakan green hospital ini dengan konsep memperluas semaksimal mungkin ruang terbuka hijau yang mampu meningkatkan kontribusi oksigen bagi lingkungan hidup di rumah sakit dan kota Jakarta pada umumnya telah sesuai dengan Visi Rumah Sakit Persahabatan yaitu: Menjadi Rumah Sakit Terdepan dalam Menyehatkan Masyarakat dengan Unggulan Kesehatan Respiratori Kelas Dunia”

\section{Ruang Lingkup Program Green Hospital RSUP Persahabatan}

Ruang lingkup program green hospital RSUP Persahabatan mengacu pada ketentuan (standarisasi) baik nasional maupun internasional. Ketentuan secara Nasional mengikuti Green Building Council Indonesia (Konsili Bangunan Hijau) dan Peraturan Menteri Negara Lingkungan Hidup RI No. 8 Tahun 2010 tentang Kriteria dan Sertifikasi Bangunan Ramah Lingkungan dan Keputusan Menteri Kesehatan Republik Indonesia Nomor:1204/Menkes/SK/2004 tentang Persyaratan Kesehatan Lingkungan Rumah Sakit. Sedangkan, ketentuan internasional mengacu pada penerapan green hospital di beberapa Negara maju seperti Amerika Serikat, Australia, Singapura, dan Lembaga International 
seperti WHO (World Health Organization), LEED (Leadership in Energy and Environmental Design).

\section{Kebijakan dan Strategik Program Green Hospital}

Hasil penelusuran dokumen yang ada didapatkan Kebijakan dan perencanaan strategi green hospital dengan visi dan misi adalah

a. Visi Green Hospital RSUP Persahabatan adalah "Menjadi Percontohan Pendidikan Green Hospital di Indonesia"

b. Misi Green Hospital RSUP Persahabatan adalah (1) Menyiapkan tenaga yang handal dan professional bidang green hospital. (2) Mengelola penggunaan dan pemberdayaan sumber daya rumah sakit berbasis green. (3) Menyediakan sarana, prasarana dan fasilitas pendidikan green hospital secara komprehensif. (4) Melakukan layanan pendidikan, penelitian dan pengembangan konsep green hospital dengan pengetahuan dan teknologi kekinian secara berkelanjutan.(6) Melakukan proses edukasi kepada masyarakat akan pentingnya hidup dan berbudaya green.

\section{Kebijakan Green Hospital}

Kebijakan dalam perencanaan strategi lingkungan di RSUP Persahabatan dalam mewujudkan green hospital adalah (1) Pemenuhan kriteria dan ketentuan green building dan green health care sesuai dengan ketentuan yang berlaku. (2) Pemanfaatan potensi hijau lingkungan rumah sakit sebagai ciri khas dan nilai jual pelayanan rumah sakit. (3) Memaksimalkan pemanfaatan ruang terbuka hijau dalam setiap pengembangan fisik rumah sakit. (4) Penerapan budaya "green" pada seluruh lapisan masyarakat rumah sakit. (5 Penerapan kaidah efisien dalam setiap pemanfatan sumber daya. (6) Penyiapan teknologi pengolahan limbah rumah sakit dengan menerapkan prinsip zero waste (minimalisasi 
limbah). (7) Menciptakan lingkungan rumah sakit sebagai lumbung oksigen dan air tanah guna pemulihan lingkungan. (8) Membangun manajemen, sistem informasi dan kemitraan dengan pihak luar.

\section{Strategi Program Green Hospital}

Pimpinan RSUP Persahabatan beserta stakeholder telah menyusun dan menerapkan perencanaan strategik lingkungan dalam mewujudkan green hospital antara lain: (1) Menyusun master plan berbasis green health care dan green building dan pemenuhan peraturan Lingkungan Hidup. (2) Menyusun strategi marketing nilai jual lingkungan hijau Rumah Sakit. (3) Mempertahankan ruang terbuka hijau maksimal 80\%. (4) Sosialisasi budaya green hospital secara berkelanjutan. (5) Pemanfaatan sumber daya energi listrik, air, kertas dan sumber daya lainnya secara efisien. (5) Penyediaan fasilitas pengolahan limbah rumah sakit. (6) Merancang inovasi dalam pemulihan mutu lingkungan hidup rumah sakit. (7) Menyusun sistem informasi lingkungan/green hospital dan kemitraan program. (8) Penyiapan sumber daya manusia yang professional dalam mengimplementasikan rencana strategik lingkungan dalam mewujudkan green hospital.

Dalam penelitian ini dipakai acuan tentang green hospital atau lebih dikenal rumah sakit ramah lingkungan adalah rumah sakit yang didesain, dibangun (renovasi) dan dioperasikan serta dipelihara dengan mempertimbangkan prinsip kesehatan dan lingkungan berkelanjutan. Kriteria green hospital yang dipakai RSUP Persahabatan meliputi: (1) Pengembangan lokasi - Sitting. (2) Efisiensi air - Water Efficiency. (3) Effisiensi energy dan pencegahan pencemaran udara - Energy and Air Pollution. (4) Material dan sumber daya Rumah Sakit - Material and Resources. (5) Kualitas Udara Indoor - Indoor Environmental Quality. (6) Makanan sehat - Health Hospital Food. (7) Pendidikan ramah lingkungan Green Education. (8) Pengadaan barang ramah lingkungan - Procurement. (9) Pencegahan 
kontaminan - Contaminant. (10) Kebersihan ramah lingkungan - Green Cleaning. (11) Pengurangan Limbah 3 R (Waste Reduction) (12) Taman Penyembuhan (Healing Gardens).

Dalam penelitian ini yang dipakai kontrol untuk perbandingan adalah Rumah Sakit Umum Pusat Fatmawati Jakarta Selatan. Tahun 2016 RSUP Fatmawati mendapat juara ke 3 lomba "penerapan Green Hospital" yang diselenggarakan Kementerian Kesehatan dalam acara puncak peringatan Hari Kesehatan Nasional ke 52 di tahun 2016, sedangkan RSUP Persahabatan tidak mendapat juara, karena pada saat diadakan penilaian telah ditemukan adanya pipa air yang bocor.

Perencanaan strategik lingkungan di Rumah Sakit Persahabatan dalam mewujudkan green hospital telah dilakukan sesuai tahapan dalam manajemen strategik yang dikemukakan Fred R. David (2011:15) yaitu

\section{Perumusan Strategik (Strategic Formulation).}

Dalam perumusan strategik dikembangkan pernyataan visi dan misi, menjalankan auidit internal dan eksternal, menetapkan tujuan jangka panjang dan merumuskan, mengevaluasi dan meilih strategi. Secara umum visi dan misi merupakan konsep perencanaan strategi yang disertai dengan tindakan untuk mencapai satu tujuan yang telah ditentukan dan ditetapkan sebelumnya. Visi adalah cara pandang ke depan tentang organisasi. Adapun Visi Rumah Sakit Persahabatan yaitu : Menjadi Rumah Sakit Terdepan dalam Menyehatkan Masyarakat dengan Unggulan Kesehatan Respiratori Kelas Dunia". Sedangkan Visi program green hospital adalah menjadi percontohan Pendidikan Green Hospital di Indonesia.

\section{Implementasi Strategik ( Strategic Implementatation)}

Implementasi strategic adalah proses dimana manajemen mewujudkan strategi dan kebijakannya dalam tindakan melalui pengembangan program, anggaran dan prosedur. Tindakan pengelolaan bermacam macam sumber daya organisasi dan manajemen yang 
mengarahkan serta mengendalikan pemanfaatan sumber-sumber daya rumah sakit (keuangan, manusia dan peralatan lain) melalui strategik yang dipilih. Implementasi strategik diperlukan untuk memerinci secara lebih jelas dan tepat bagaimana sesungguhnya pilihan strategik yang telah diambil untuk direalisasikan. (Wheelen and Hunger : 2012)

\section{Evaluasi Strategik ( Strategic Evaluation)}

Secara umum ada tiga aktivitas dalam melakukan evaluasi strategi: (1) Meninjau faktor-faktor eksternal dan internal yang menjadi dasar strategi yang ada sekarang ini. (2) Meninjau pencapaian target yang telah ditetapkan. (3) Mengambil tindakan korektif.

Berdasarkan temuan dari penelitian dan pembahasan serta kesimpulan Perencanaan Strategik Lingkungan Rumah Sakit Persahabatan dalam mewujudkan Green Hospital, maka disusun rekomendasi ditujukan kepada:

1. Rumah Sakit Umum Pusat Persahabatan

Rumah sakit yang sedang menerapkan program green hospital perlu konsisten dalam proses strategik manajemen (strategik manajemen process) dengan fokus environmental strategic planning yaitu formulasi strategi (strategic formulation), implementasi strategik (strategic implementation) dan evaluasi strategik (strategic evaluation). Dalam mewujudkan program green hospital hendaknya tetap konsisten melakukan environmental strategic planning yang meliputi Analisa SWOT, mengikuti standart Green Hospital dari Kementerian Kesehatan, yang berfokus pada green building, kesehatan lingkungan dan budaya green sebagai penerapan budaya organisasi.

2. Kementerian Kesehatan Republik Indonesia.

Dalam implementasi kebijakan green hospital, kementerian Kesehatan Republik Indonesia, hendaknya tetap fokus dan konsisten dengan standard yang telah ditetapkan, sehingga ke dua belas (12) standard tersebut dapat diwujudkan. Pelaksanaan program green hospital dapat dievaluasi melalui proses strategik manajemen lingkungan rumah sakit, 
sehingga persyaratan green building, efisiensi sumberdaya energy listrik, air dan pengolahan limbah dapat sesuai dengan peraturan yang berlaku. Pendidikan lingkungan hidup dengan budaya green sehingga dapat meningkatkan derajat kesehatan masyarakat. Kementerian Kesehatan RI perlu mengadakan lomba penerapan green hospital setiap tahunnya pada seluruh rumah sakit, dan pemberian sertifikat Green Hospital.

\section{KESIMPULAN}

Berdasarkan kriteria strategik manajemen yang berfokus pada perencanaan strategik lingkungan yang diterapkan di rumah sakit Persahabatan, komponen strategik manajemen, perbandingan penerapan green hospital di RSUP Fatmawati, sebagai kontrol dalam penelitian dan kriteria green hospital, maka dapat disimpulkan berdasarkan temuan:

Apabila manajemen rumah sakit diarahkan menjadi green hospital, maka perlu diperkuat strategik manajemen lingkungan rumah sakit dengan fokus pada strategic planning yang meliputi komponen-komponen seperti analisis faktor internal dan eksternal dengan melaksanakan analisis SWOT, menetapkan visi dan misi serta budaya organisasi yang kondusif melalui penetapan slogan.

\section{DAFTAR PUSTAKA}

Azhary,M. Emil. Potret Bisnis Rumah Sakit Indonesia. Economic Review. No.218.Desember 2009.

Azmal, Mohammad et al, Going to wad Green Hospital by Sustainable HealthcareWasteManagement.http://dx.doi.org/10.4236/heal.2014619302

Balifokus.Activity Report. Assesment of Environmental Conditions and Inventory for Guidence and Technical Support to Develop Sound Management Practices for Hospital Wastes. February 2010.

Barrow, C.J. Environmental Management for sustainable Development: New York, Routledge 2044. 
Bryson M.John. Strategic Planning for Public And Nonprofit Organizations.Third Edition..San Francisco.John Wiley \& Sons 2004

Chiras, Daniel,D.Enivironmental Science: Action for a Sustainable Future,Redwood City California : The Benyamin Cummings Publishing, 1991

Chiras. Daniel R. Environmental Science. A, Framework for Decision Making. The Benyamin.Cummings Publishing Company Inc.1985.

David, $R$. Fred, Strategic Management, Concepts and Cases, (New Jersey: Prentice Hill, 2011)

Energy Conversion and Management. Energy consumtion indicator and CHPtechnical potential in the Brazillian hospital sector, 2004

Energy Conversion and management. Energy Consumtion Indicator and CHP technical potential in the Brazilian hospital sector, 2004.

Enger, Eldon Brad Smith, Environmental Science. A study of Interrelationships. Eleventh Edition.Boston :Mc Graw Hill Higher Education 2008.h2.

Farid Zamakhasari A: Implementasi konsep Green Hospital pada Rumah Sakit Panti Nugroho Yogyakarta.

Hosseini, Farzianpour,F.,S. and Hosseini,S. (2014) Global Change and Human Health, $2^{\text {nd }}$ International Conggres on Energy Efficiency and Energy Related Materials Libery Hotels Lykia,Oludeniz, 16-19 October 2014,365.www.enefm 2014.0rg

Hill .Charles W. Hill and Gareth Jones, The Essentials of strategic Management, (Boston: Prentice Hall,2012)

http/www.sumeks.co.id

http://www.cartridgerescue.com.au

International trade Administration. China Healthcare Contruction Market,2005. http://www.ita.doc.gov/td/health/china Healthcare Contruction05.pdf

Kuhre,W.Lee. ISO 14001 certification Environmental Management Systems.,Prentice Hall PTR;1995.

Madu,Christian N, Environmental Planning and Managmenent, Imperial College Press: London

McNougthon, "Carapedia Environmental Management", dalam http://carapedia.com/pengertian_definisi_lingkungan_hidup__ menurut__para _ahli_info951.html

Miller and Taylor, Living in the Environmental an Introduction to Environmental Science, California Bermont:1986 
Mohammad Azmal: Going toward Green hospital by Sustainable Healthcare Waste Management: Segregation, Treatment and Safe Disposal. http://www.scirp.org/journal/health.

National Health Service, Sustainable Development Unit. Saving Carbon, Improving Health: NHS carbon reduction strategy, Cambrige, January 2009.

National Health Service, Sustainable Development Unit. Saving carbon, improving health: NHS carbon reduction strategy. Cambridge, Januari 2009

Odum. Eugene P. Fundamental of Ecology. Third Edition. Philadelphia: W.B. Saunders Company, 1971

Partakusuma, Lia G. Mohamad Nasir, Muslina Hanyani, Green Hospital, Perhimpunan Rumah Sakit Seluruh Indonesia (PERSI). 2014.

Daft, Richard,1. New Era Of Management $9^{\text {th }}$ ED , Singapore: Thomson Learning Publlisher Burden E.Books.2003

Richey, Rita C. and James D. Klein, Designd and Development Research, Methods, Strategies and Issues, London: Lawrence Erlbaum Associates Publisher. 2007,

Technical bulletin green hospital - indian green building council

Velasquest, Horatio. Polution Control: Management, Technology and Regulation ,New York: Nova Science Publisher, 2011.

Wali, Mohan K.,Falih Evrendilek \& M. Siobhan Fenneshy. The Environment, Science, Issues and Solution, New York:CRC Press Taylor \& Francis Group,2010.

Wheelen, Thomas, and David Hunger, Strategic Management and Business Policy, Toward Global Sustainability, Florida:Pearson, Bentley University, 2012

WHO Technical Report Series, No.122. 1957. Role Hospital in Programmes of community Health Protection, first report of the expert Committee on Organization of Medical Care.

Wiersma, James. Michael D.Morgan, Joseph M.Moran, Introduction to Environmental Science, New York, USA: W.H. Freeman and Company, 1986

World Health Organization. Health in the Green Economy: Co-Benefits to Health of Climate Change Mitigation. Health Facilities.2010

World Health Organization. Health in the Green Economy Co-Benefits to Health of Climate Change Mitigation. Health Facilities 2010. 